\title{
El desasosiego de Michael Haneke
}

\author{
CrisTina López DelGado
}

Cáceres
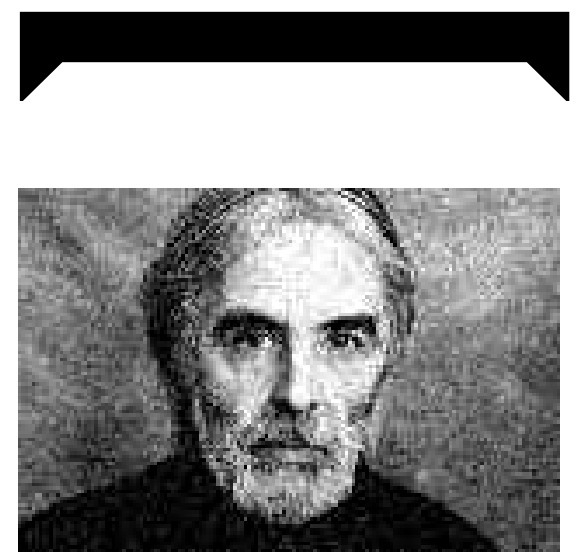

En los relatos de Haneke, el hostigamiento de los personajes rebota necesariamente en el espec-

tador. Atosiga su conciencia. Le incomoda y le

hace removerse en su butaca. iExiste un límite

ente la ficción y la realidad?

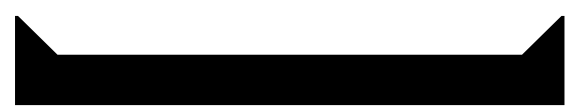

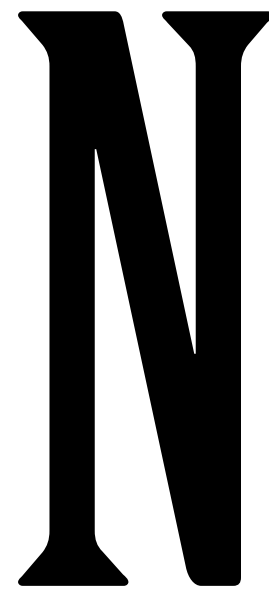

Nacido en Múnich (Alemania) en 1942 y afincado en Viena desde su juventud, el director Michael Hanekeno deja lugar a la indeferencia. Estudió Filosofía y Psicología antes de dedicarse a la dirección. Su controvertido cine refleja sus inquietudes existencialistas y su desasosegante visión del mundo occidental. Sus tres primeros largometrajes son conocidos como la «Trilogía de la glaciación emocional»: El séptimo continente (Der Siebente Kontinent, 1989) muestra el derrumbe de una familia burguesa vienesa atrapada en sus propias convenciones; El vídeo de Benny (Benny's Video, 1992) presenta a un adolescente que lleva al extremo su obsesión por la violencia; y 71 momentos para una cronología del azar (71 Fragmente einer Chronologie des Zufalls, 1994) se construye a partir de un acto de violencia totalmente aleatoria en forma de tiroteo indiscriminado en un banco. A través de ellos sitúa el turbador ojo de su cámara en los rincones más oscuros de la condición humana. En 1996 dirigió El castillo (Das Schloss), una fiel reconstrucción de la fragmentaria novela de Frank Kafka. Su categórica visión del comportamiento psicópata quedó patente en Funny Games (1997), una película asfixiante y terrorífica; planteó escenas apocalípticas sobre lo abyecto del comportamiento del ser humano en circunstancias extremas en El tiempo del lobo (Le Temps du loup, 2003), con la que inicia su fase de creación en lengua francesa, y una similar crudeza emocional caracteriza a películas como La pianista (La pianiste, 2001), un relato sobre cómo conviven lo sublime y lo sórdido en la perturbadora existencia de una mujer, o Código desconocido (Code unconnue,
2000), combinación de varios escenarios unidos por el tema común de la comunicación, o la imposibilidad de comunicación en el mundo actual, y los motivos sociales, étnicos y xenófobos que propician esta situación. En su último trabajo, $\mathrm{Ca}$ ché - Escondido (Caché, 2005), recurre al sentimiento de culpa y a la inseguridad emocional para dar vida a la conmoción de una familia cuya rutina diaria se ve alterada por unas desconcertantes grabaciones clandestinas de vídeo.

\section{Un desolador viaje de ida y vuelta}

En los relatos de Haneke, el hostigamiento de los personajes rebota necesariamente en el espectador. Atosiga su conciencia. Le incomoda y le hace removerse en su butaca. ¿Existe un límite ente la ficción y la realidad? ¿Dónde se sitúa la barrera que nos hace sentirnos cómodos delante de la pantalla? Haneke desplaza esa barrera a su antojo haciendo evidente en sus creaciones la imposibilidad del espectador pasivo. Le somete a un atosigamiento del que es imposible huir sin implicarse. La película atrapa al espectador. $\mathrm{Y}$ avanza porque éste la obliga a avanzar. Cuando piensa ¿qué es esto?, ¿qué va a suceder ahora?, se da cuenta de que sigue intuitivamente el pensamiento del propio protagonista. En Caché, llega un momento en que las imágenes que estamos viendo son desconcertantes para el espectador, le descolocan. La reacción del protagonista marcha al unísono con nuestro pensamiento y rebobina la cinta en busca de una aclaración. El espectador accede al terreno de ficción y forma ya parte de la película. En un efecto análogo, la perturbadoramente amable mirada de Arno Frisch en Funny Games sobrecoge cuando guiña el ojo al espectador para confirmar que éste intuye el resultado del juego de búsqueda con el que martirizan a la madre. El guiño significa «exacto, tal y como estabas pensando, hemos matado al perro».

La legitimación de la violencia es un hecho incuestionable en el cine de nues- 


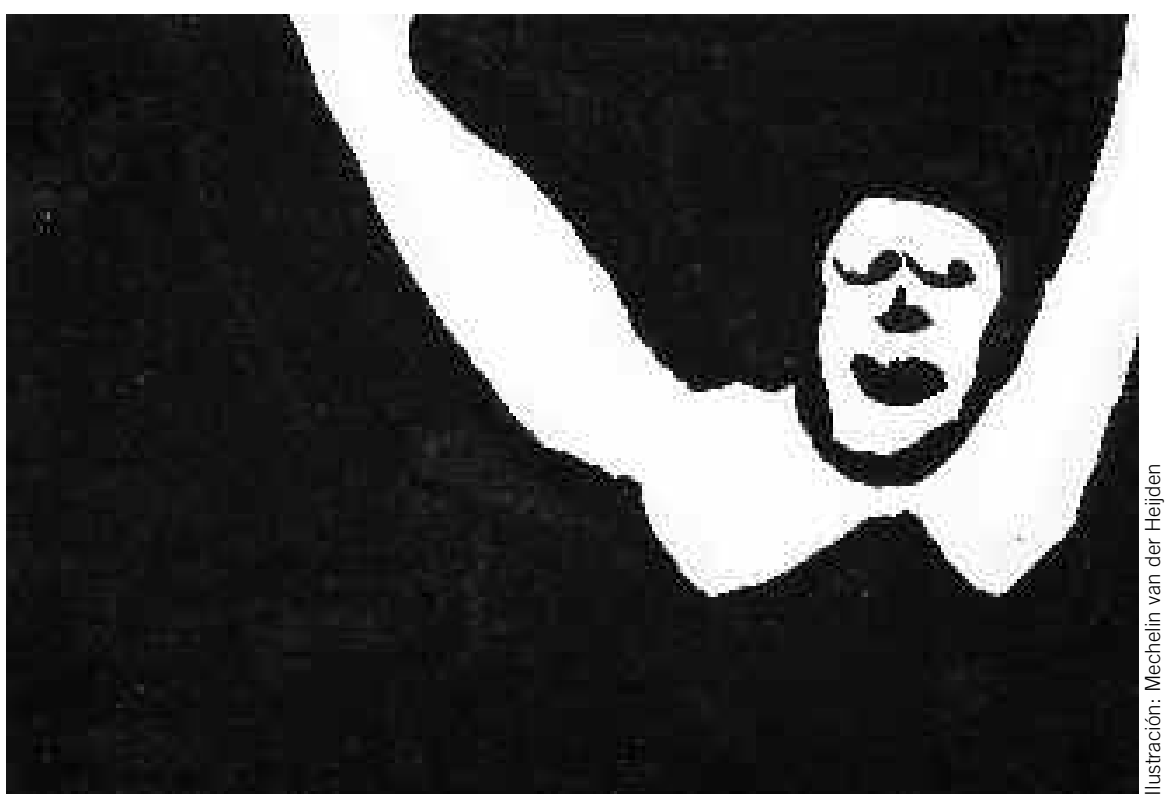

tros días. El público comparte deseos de venganza con el protagonista que se asientan en un suceso conocido. Según la incisiva mirada de Haneke, la violencia tratada de una forma justa convierte la película en un objeto insoportable. El control de la violencia en el cine es el único posible. Para desmontar este argumento, Haneke nos hace confundir ficción con realidad y nos ofrece una ficción que tampoco logra mantener la violencia bajo control. No da tregua al espectador. El maltratador rebobina la cinta en Funny $\mathrm{Ga}$ mes y hace valer su propósito, no permite un desenlace esperanzador al menos para uno de los personajes. Pues si sucede en la ficción, será real, ya que es delgada la línea que une ambos mundos como queda patente en la conversación final entre los dos torturadores en la barca: «La ficción es real ¿no?» Si lo ves en una película es tan real como la realidad que ves. No se trata de pesimismo sino de realismo en palabras del propio director. Tratar de encontrar una explicación lógica a la violencia carece de sentido. Ante la desesperada pregunta de las víctimas a sus torturadores de "¿Por qué hacéis esto?", no pueden más que responder un «¿Por qué no?» que hunde al espectador aún más es la desolación y la angustia que le sobrecogen desde el principio. Los sádicos protagonistas de Funny Games no distinguen entre realidad y ficción, mezclan ambos planos en una especie de amalgama de devastadores efectos.

Haneke da tiempo para pensar. Provoca reacciones, ideas, conjeturas. No facilita desenlaces. No considera la posibilidad de aportar una solución. El propio espectador decide, crea la película. Descubre por cuenta propia un mundo que se presenta velado, enredado. Una cinta que va y viene, que se rebobina para darte tiempo a pensar como en Caché. O para acabar con tus posibilidades de ver un desenlace más propicio que supusiese un alivio y una forma de triunfo, como en Funny Games. No cabe esa posibilidad. Estamos mediatizados por la norma en las representaciones cinematográficas "violentas», que acaban aportando un respiro al espectador, que se atienen a un código no escrito que marca los límites de lo permisible. En las películas de Haneke, en realidad menos «violentas» por su representación elíptica de las escenas más crudas, que, en consecuencia y tal y como preten- de este creador, se desarrollan en la mente del espectador, necesitan de su imaginación para tener lugar. Se le proporcionan las opciones. Si participa activamente, y reconstruye mentalmente la escena fuera de plano en Funny Games, descubrirá contando hasta 35 quién ha sido el miembro de la familia seleccionado para morir en primer lugar. Sólo queda que la cámara desvíe la atención del aparato de televisión salpicado de sangre (una vez más la reiterada atribución de responsabilidad a los medios de comunicación tan explícita siempre en Haneke), para confirmar nuestras sospechas.

Nos desconcierta con el desconcierto de unos protagonistas que no saben qué sucede. Que son victimas aleatorias. No son «malos», no han cometido actos deplorables. Los personajes están desolados, no entienden por qué son las víctimas, tratan de buscar una explicación. El conflicto está planteado, la misión cumplida. Pero, ¿quién ejecuta esta misión y por qué? ¿Por qué asesinan los psicópatas de Funny Games? Se burlan de la ficción clásica, hambrienta de justificaciones que calmen nuestra mala conciencia por el placer con que contemplamos la venganza. Uno de los torturadores presenta a su compañerocomomiembro de una familia desestructurada en una especie de broma macabra que proporcionaría al espectador y a las víctimas un falso consuelo para su desesperación. ¿Qué razones tiene el protagonista del Vídeo de Benny para asesinar a su amiga? La única evidente es su afición por el cine gore y su deseo de grabar el asesinato en vídeo. ¿Es esto una justificación?

La angustia sin límites, la desolación máxima, la asfixia. El horror de unas escenas carentes de horror. De una elipsis de imágenes aterradora y desesperante. Las películas de Haneke no pretenden aportar una respuesta a nada. No van más allá, es el espectador quien va más allá por su cuenta y busca esa respuesta. Es ese espectador que se remueve incómodo en la butaca quien llegará a sus propias conclusiones. 